\title{
Frisian strong and weak verbs in the face of Dutch influence: a synchronic and experimental approach
}

\author{
Remco Knooihuizen ${ }^{1}$. Odile A. O. Strik ${ }^{2}$. \\ Gerbrich de Jong ${ }^{1}$
}

Received: 8 July 2016 / Accepted: 1 October 2017 / Published online: 13 March 2018 (C) The Author(s) 2018

\begin{abstract}
Like other Germanic languages, Frisian has both strong and weak verbal inflection. Despite a strong diachronic tendency for change towards weak inflection, strong inflection patterns are available synchronically to speakers to form the past tense and past participle of new or nonce verbs. Using a measure for 'potential productivity' developed by Knooihuizen and Strik (Folia Linguist Hist 35:173-200, 2014) for Dutch, we investigate the relative strength of available patterns in Frisian in an elicitation and an acceptability judgment experiment. Despite the multitude of different patterns in the strong verbal inflection system, strong inflection makes up 35\% of the elicited nonce forms; these forms cannot all be explained by analogy. Analogically formed strong inflections of nonce verbs receive relatively high acceptability ratings at 4.2 on a 7-point scale. The elicitation experiment also produced many weak forms (12\% of participles) that are not normatively possible with the $-e$ infinitives in the elicitation prompt. These alternative weak forms were not included in the acceptability judgment experiment. We discuss the experimental results in the context of diachronically attested language change in Frisian and of intensive language contact with Dutch.
\end{abstract}

Keywords Analogy · Dutch · Frisian · Morphology · Productivity · Verbal inflection

Remco Knooihuizen

r.m.knooihuizen@rug.nl

Odile A. O. Strik

oscar.strik@uantwerpen.be

1 Centre for Language and Cognition Groningen, Rijksuniversiteit Groningen, Postbus 716, 9700

AS Groningen, The Netherlands

2 Universiteit Antwerpen, Rodestraat 14, room R.216, 2000 Antwerpen, Belgium 


\section{Introduction}

In recent years, there has been a growing interest in verbal inflection class change in the Germanic languages. While there is as yet no overarching work that comparatively charts, models or explains the historical development of strong and weak verbal inflection, studies on individual languages have filled in some of the blanks: see, e.g., Nowak (2015) for German, Dutch, and Luxembourgish; Dammel (2011) for German; Pijpops et al. (2015) for Dutch; and Strik (2015) for Swedish and Frisian.

Moving from history to contemporary inflection, we find quite a few studies on the psycholinguistic processing of regular versus irregular inflection (see Strik 2015: 25-27 for a summary), as well as studies that evaluate the synchronic productivity of different verbal inflection strategies (summarised below). In this article, we want to shed light on two aspects simultaneously: the synchronic potential productivity of competing inflection patterns, and the extent to which language contact influences that competition between patterns. We do this by eliciting past tense and past participle inflections of nonce verbs from speakers of Frisian, ${ }^{1}$ and by letting participants assign a rating to both a weak and a strong alternative for a different set of nonce verbs.

In the analysis that follows, we examine the differences in potential productivity between extant inflectional patterns of Frisian, and compare the Frisian results to those obtained for Dutch in Knooihuizen and Strik (2014).

\section{Background}

\subsection{The sociolinguistics of Frisian-Dutch language contact}

Frisian is a co-official language with Dutch in the province of Fryslân (Dutch: Friesland) in the north of the Netherlands. It is relatively widely spoken and understood: $94 \%$ of the province's population of approx. 650,000 can understand Frisian, 74\% speak it, 65\% can read it, but only 17\% can write it (Gorter 2001: 74). Swarte and Hilton (2013) cite a figure of $64 \%$ who speak Frisian 'well' or 'very well', giving a speaker number of approx. 400,000.

It is reasonable to assume that all speakers of Frisian, with the exception of some pre-school children, also have mother-tongue proficiency in Dutch. In fact, Dutch has a stronger social position because it is used in more domains than Frisian (Breuker 2001: 127-128). Attitudes to Frisian are generally positive among its speakers; non-speakers tend to have much less positive attitudes (Hilton and Gooskens 2013).

As the languages, or rather their speakers, have been in intensive contact for a long time, and because the two languages already share similarities from the outset, we expect convergence between Frisian and Dutch. Intensive contact tends to facilitate contact-induced change, in particular the transfer of structural features (Thomason 2010: 36-37), and hence to convergence between the two languages involved (even if one language may be 'moving' more than the other). Contact-induced change is

\footnotetext{
1 We use 'Frisian' as a shorthand for the variety spoken in the province of Fryslân in the Netherlands, more accurately known as West or Westerlauwers Frisian.
} 
thought to be easier when the languages involved are similar (Siegel 2001: 191), although intensity of speaker contact is argued to be the more important factor (Bowern 2013). The widespread bilingualism also leads to contact-induced innovations being more easily recognised and picked up, and to them spreading more easily through the community (see, e.g., Matras 2009: 76).

Some scholars identify a variety of Frisian with significant Dutch influence: Interference Frisian (de Haan 1997). However, as virtually all speakers of Frisian are bilingual in Dutch, we may expect influence from Dutch (interference) in all forms of Frisian. While a distinction between Interference Frisian and geef Frysk 'pure Frisian'-wherever you draw the line-may be useful for some research, we do not think it is helpful in studies of Dutch-Frisian interference in particular.

\subsection{Variation and change in the Germanic verb system}

The past tense and perfect participle of verbs in Germanic languages can, with some idiosyncratic exceptions, be formed using one of two strategies. Most verbs use a suffix with a dental, as in (1); these are called 'weak verbs'. A much smaller group of 'strong verbs' - their number varies significantly between different Germanic languages-do not use a suffix in the past tense, and use a suffix with a nasal in the perfect participle. ${ }^{2}$ In the vast majority of strong verbs, the vowel in the verb stem also changes. An example of a strong verb in different Germanic languages is given in (2). ${ }^{3}$

(1)

$\begin{array}{lll}\text { thank- } & \text { thank-ed } & \text { thank-ed } \\ \text { dank-en } & \text { dank-te } & \text { ge-dank- } \boldsymbol{e} \\ \text { takk-e } & \text { takk-ede } & \text { takk-et } \\ \text { takk- } \boldsymbol{a} & \text { takk-aði } & \text { takk-að }\end{array}$

$\begin{array}{lll}\text { blijv-en } & \text { bleef } & \text { ge-blev-en } \\ \text { bleiw-en } & \text { blouf } & \text { bliww-en } \\ \text { blív-a } & \text { bleiv } & \text { bliv-in } \\ \text { bli- } & \text { blev } & \text { bliv-it }\end{array}$
(English)
(German)
(Danish)
(Faroese)

The majority of Germanic verbs are weak; Seebold's (1970) barely abridged overview of the Germanic strong verb lists some 500 strong verbs in total, but many of these do not occur in all Germanic languages, and the overwhelming diachronic tendency has been for strong verbs to become weak. With few exceptions, loan words

\footnotetext{
2 Weak and strong verbs are often referred to as 'regular' and 'irregular', respectively. We refrain from this usage since, as the discussion will show, there is often a lot of regularity in strong verbal inflection, and weak inflection has irregular exceptions.

3 Throughout the paper, when we give verbal inflection paradigms, they are in the order infinitive, past tense (3rd person singular), past participle. In the running text, forms in paradigms are separated by a midpoint (•). Some of the examples in (1) and (2) do not strictly adhere to the definitions of 'strong' and 'weak' verbs we have given here. For example, the weak past tense suffix in Faroese is pronounced /aji/, the perfect participle ending is /a/. Because these forms are the result of regular sound change from an original dental suffix, we count them as falling within our definition. The Swedish form blivit in (2) is a supine, which is based on the neuter form of the perfect participle and which has completely replaced the participle in most Mainland Scandinavian varieties.
} 
and neologisms are also inflected according to the weak pattern, e.g. Dutch appen appte $\bullet$ geappt 'send a WhatsApp message'. Two other types of change do also happen, however: weak verbs can become strong, e.g. Dutch breien • bree • gebreeën 'knit' (in addition to weak breide $\bullet$ gebreid; Geerts et al. 1984: §8.3.5.ii.a.1.b), Yiddish šextn • gešoxtn 'slaughter' (< Hebrew šăhat; Jacobs 2005: 214); and strong verbs can change their vowel alternation pattern, as the English past tense bit for bite (the Old English past tense $b \bar{a} t$ should, with regular sound change, give Present Day English bote).

When a new form is coined according to a pattern, or part of a pattern, we define this pattern to be 'productive'. Productivity, therefore, is not restricted to a single form or pattern: as the examples above show, both weak and strong inflection patterns and parts of these patterns can be productive at the same time. The difference between the productivity of these patterns is a matter of degree: weak inflection is a highly productive pattern, while the use of $/ \mathrm{I} /$ in the English past tense (as in bit) is only minimally productive. The possibility of multiple productive patterns need not be at odds with notions such as 'defaultness' and 'unmarkedness', although the relationship between these concepts is not straightforward. In particular, although this is often the case, the most productive form in terms of type frequency need not be the most productive in terms of scope of applicability, and as such does not necessarily qualify as the 'default' (see the discussion in Strik 2015: 16-17).

The relative productivities of different patterns can be gleaned from an analysis of changes in the history of a language. From such an analysis, it is immediately clear that pattern productivity is particular to a time and a place: in 16th- to 18th-century Dutch, for example, we see a spread of the vowel /i/ to the past tense forms of certain verbs (helpen $\bullet$ holp $>$ hielp 'help', sterven $\bullet$ storf $>$ stierf 'die', werpen $\bullet$ worp $>$ wierp 'throw', among others; Heinsius 1897: 59-60; van den Berg 1957). In later Dutch, or other Germanic languages, we do not see this development.

Productivity, then, leaves us with a paradox: it is punctual and synchronic, but it can only be investigated diachronically on the basis of changes that have run to (near-) completion. We have therefore coined the term 'potential productivity': the ease with which alternative rules may be selected and applied (see also Knooihuizen and Strik 2014). Potential productivity is synchronic. It can be seen in variation, and can be tested experimentally: see Moder (1992) and Cuskley et al. (2015) for English, Clahsen (1997) for German, Ragnarsdóttir et al. (1999) for Icelandic and Norwegian, Knooihuizen and Strik (2014) for Dutch, and this paper for Frisian. These studies unequivocally show that weak inflection has the highest potential productivity of all inflection patterns: $61 \%$ of all possible experimental forms in English, and 68\% in Dutch, were formed according to that inflection pattern; moreover, there are fewer constraints (e.g., specific root vowels or stem coda consonants) on the application of weak inflection than on the application of any other pattern.

The methodologies used in Moder (1992) and Knooihuizen and Strik (2014) are comparable, but we do not necessarily want to conclude from these numbers that weak inflection has a higher potential productivity in Dutch than in English. The potential productivity of weak inflection is probably underestimated in both studies as many test tokens were intentionally similar to existing strong verbs, and the results therefore probably overestimate the potential productivity of strong inflection patterns. These numbers also leave out any additional constraints on the application of the pattern. 
For example, Knooihuizen and Strik (2014) estimate the productivity of the / $/ \mathrm{I} / \bullet$ /e/ • /e/ pattern in Dutch (Class I) at a relatively high $17 \%$, but this pattern can only be applied to verbs with an $/ \varepsilon \mathrm{\varepsilon} /$ in the stem, and appears to have a considerably higher productivity if the stem coda contains a stop or fricative rather than a liquid or nasal, and for forming past tense forms rather than perfect participles.

\subsection{Dutch and Frisian verbs compared}

Although Dutch and Frisian are closely related languages and share a centuries-long history of contact and possible convergence, there are a number of striking differences between the verbal inflection systems of the two languages. The first of these is that Dutch has a single class of weak verbs, exemplified in (3), while Frisian has two classes, as in (4).

$$
\begin{array}{lllll}
\text { fiets-en } & \text { fiets-te } & \boldsymbol{g} \boldsymbol{e} \text {-fiets- } \boldsymbol{t} & \text { 'cycle' } & \text { (Dutch, weak) } \\
\text { hel-en } & \text { heel-de } & \boldsymbol{g} \boldsymbol{e} \text {-heel- } \boldsymbol{d} & \text { 'heal' } & \text { (Dutch, weak) }
\end{array}
$$

$\begin{array}{llllll}\text { a. } & \text { bakk- } \boldsymbol{e} & \text { bak-te } & \text { bak- } \boldsymbol{t} & \text { 'bake' } & \text { (Frisian, weak-1) } \\ & \text { rein- } \boldsymbol{e} & \text { rein- } \boldsymbol{e} \boldsymbol{e} & \begin{array}{l}\text { rein- } \boldsymbol{d} \\ \text { b. rain' }\end{array} & \text { (Frisian, weak-1) } \\ \text { b. wurk-je } & \text { wurk- } \boldsymbol{e} & \text { wurk- } \boldsymbol{e} & \text { 'work' } & \text { (Frisian, weak-2) }\end{array}$

The Frisian weak-1 class, signalled by an infinitive ending in - $e$, is clearly parallel to the Dutch weak class, and follows the same rules for voiced and voiceless allomorphs: stems ending in a voiceless sound (before the application of the final devoicing rule) take the $t$-allomorph, and stems ending in a voiced sound take the $d$-allomorph. The Frisian weak-2 class, with infinitives ending in -je, does not have a parallel in Dutch. Loan words in both languages are normally inflected according to the weak pattern, e.g. Dutch scoren • scoorde • gescoord 'score', stimuleren • stimuleerde • gestimuleerd 'stimulate'; Frisian skoare • skoarde • skoard (weak-1), stimulearje • stimulearre • stimulearre (weak-2). It is generally assumed that weak-2 is the default verbal inflection class in Frisian. This assumption is based on pure numbers (the weak-2 class is much bigger than the weak-1 class) and on the fact that verbs derived by suffixation or conversion all have je-infinitives (Hoekstra 1998: 141). A number of loanwords (such as skoare < Du. scoren) do end up in the weak-1 class, however. Although the distribution of new verbs across the two weak classes is not entirely predictable, Haverkamp et al. (submitted) show that there is a tendency for monosyllabic stems with simple codas to end up in the weak-1 class, and for polysyllabic stems with complex codas to end up in the weak- 2 class.

Further differences between Dutch and Frisian can be found in the strong verbs. Firstly, Dutch has considerably more strong verbs than Frisian (approximately 220 vs. 160, De Backer 2013: 103). Moreover, Dutch has considerably fewer vowel alternation patterns than Frisian: Geerts et al. (1984: §8.3.5.ii.a) list 23 different patterns for Dutch, while Eisma and Popkema (2004: 70-78) have no less than 76 different patterns for Frisian, more than three times as many. The traditional Germanic ablaut patterns are generally retained in Dutch (Table 1): a small number of patterns have relatively many member verbs, with the rest being idiosyncratic for only one or two verbs. Because of 
Table 1 Strong verb classes in Dutch

\begin{tabular}{|c|c|c|c|c|}
\hline \multirow[t]{2}{*}{ Class } & \multicolumn{3}{|c|}{ Alternation pattern } & \multirow[t]{2}{*}{ Examples } \\
\hline & Infinitive & Past tense & Participle & \\
\hline I & /عI/ & /e/ & /e/ & grijpen, kijken, schrijven \\
\hline II a & /i/ & /o/ & $10 /$ & liegen, bedriegen \\
\hline II b & /œy/ & /o/ & /o/ & zuigen, ruiken \\
\hline III a & $/ \mathrm{I} / \sim / \varepsilon /$ & $/ 2 /$ & $/ 2 /$ & drinken, schenken \\
\hline III b & $\mid \varepsilon /$ & $/ \mathrm{i} /$ & $/ 2 /$ & sterven, helpen \\
\hline IV & /e/ & $/ \mathrm{a} /$ & $10 /$ & spreken, breken, nemen \\
\hline V & $/ \mathrm{e} / \sim / \mathrm{I} /$ & $/ \mathrm{a} /$ & le/ & geven, bidden, lezen \\
\hline VI & /a/ & $/ \mathrm{u} /$ & $/ \mathrm{a} /$ & varen, dragen \\
\hline VII a & any & /i/ & as inf & blazen, lopen \\
\hline VII b & $/ \mathrm{a} /$ & $/ \mathrm{I} /$ & $/ \mathrm{a} /$ & vangen, hangen \\
\hline
\end{tabular}

diachronic phonological change in Frisian, the seven ablaut classes have not been so clearly retained in that language as they have in Dutch, and the Frisian patterns have relatively fewer members. In Table 2, we show the one-to-many correspondences between the Dutch ablaut classes and the Frisian inflection groups. Although this is by no means a comprehensive overview, it should sufficiently illustrate the greater diversity in Frisian vowel alternation patterns. Note also that the table only shows the spelling of the Frisian forms; the precise pronunciation varies considerably across the Frisian language area.

We cannot give a comprehensive overview of the development of strong verbs in Frisian. For that, we refer the reader to Strik $(2014,2015)$, from which we wish to highlight four salient developments in the Frisian strong verb system that clearly set it apart from Dutch.

(i) A subgroup of Class I verbs with stem coda /w/ were subject to so-called 'Jorwert breaking' (Dyk 2007) resulting in Pattern B, e.g. skriuwe • skreau • skreaun 'write', which is markedly different from the original Class I retained in Pattern A.

(ii) In a subgroup of Class III verbs with the Old Frisian stem rhyme /ind/, regular loss of /d/ after /n/ resulted in Pattern I (e.g. fine • fûn • fûn 'find'), which later analogically attracted verbs with short stem vowel /I/ (Pattern J).

(iii) Past tense forms with ie developed regularly in Class IV and spread from there to some Class V verbs (Pattern P). Note that this is a separate development from the spread of ie past tense forms from Class VII to Class IIIb in Dutch.

(iv) Where such Class IV and V verbs had stem coda $/ \mathrm{k} /$, there was regular palatalisation and subsequent assibilation to /ts/ in the participle, which in some varieties has spread analogically to the past tense. We return to these so-called 'assibilation verbs' (Pattern O, e.g. sprekke • spriek $\sim$ spruts • sprutsen 'speak') in our discussion. 
Table 2 Overview of major correspondences between Dutch verb classes and Frisian verbal inflection patterns. (The Frisian Pattern D corresponds to two separate Dutch classes)

\begin{tabular}{|c|c|c|c|c|c|c|}
\hline \multicolumn{3}{|l|}{ Dutch } & \multicolumn{4}{|l|}{ Frisian } \\
\hline Class & $n$ & Examples & Pattern & Alternation $(\mathrm{Inf} \bullet$ Past $\bullet$ Pcpl) & $n$ & Other examples \\
\hline \multirow[t]{2}{*}{ I } & 55 & rijden & A & ride $\bullet$ ried $\bullet$ riden & 22 & stride, belide \\
\hline & & schrijven & B & skriuwe $\bullet$ skreau $\bullet$ skreaun & 10 & bliuwe, driuwe \\
\hline \multirow[t]{2}{*}{ II a } & 13 & vriezen & $\mathrm{C}$ & frieze $\bullet$ frear $\bullet$ ferzen & 2 & ferlieze \\
\hline & & schieten & $\mathrm{D}$ & sjitte $\bullet$ skeat $\bullet$ sketten & 2 & mjitte \\
\hline \multirow[t]{2}{*}{ II b } & 24 & sluiten & $\mathrm{E}$ & slute $\bullet$ sleat $\bullet$ sletten & 1 & - \\
\hline & & kruipen & $\mathrm{F}$ & krûpe $\bullet$ kroep $・$ krûpen & 6 & dûke \\
\hline \multirow[t]{2}{*}{ III $a+b$} & 46 & drinken & G & drinke $\bullet$ dronk $\bullet$ dronken & 23 & sinke, swimme \\
\hline & 7 & helpen & $\mathrm{H}$ & helpe $\bullet$ holp $\bullet$ holpen & 6 & smelte, melke \\
\hline (a) & & vinden & I & fine $\bullet$ fûn $\bullet$ fûn & 6 & bine, swine \\
\hline (a) & & winnen & $\mathrm{J}$ & winne $\bullet$ wûn $\bullet$ wûn & 5 & spinne, begjinne \\
\hline (b) & & werpen & K & werpe $\bullet$ wurp $\bullet$ wurpen & 8 & merke, swerve \\
\hline (b) & & sterven & $\mathrm{L}$ & stjerre $\bullet$ stoar $\bullet$ stoarn & 3 & bedjerre, ferdjerre \\
\hline \multirow[t]{2}{*}{ IV/V } & 6 & nemen & M & nimme $\bullet$ naam $\bullet$ nommen & 1 & - \\
\hline & 11 & bidden & $\mathrm{D}$ & bidde $\bullet$ bea $\bullet$ bean & 3 & - \\
\hline VI & 5 & dragen & $\mathrm{N}$ & drage $\bullet$ droech $\bullet$ droegen & 4 & grave \\
\hline \multirow[t]{2}{*}{ various } & & & $\mathrm{O}$ & sprekke $\bullet$ spriek $\bullet$ sprutsen & 9 & strekke, trekke, stekke \\
\hline & & & $P$ & stelle $\bullet$ stiel $\bullet$ stellen & 6 & frette, lêze, sitte \\
\hline
\end{tabular}

As Frisian has fewer strong verbs than Dutch, it is no surprise that a quite a number of Frisian verbs are weak while their Dutch cognates are strong. Eisma and Popkema (2004: 21) mention examples from the largest Dutch inflection classes I and II. The opposite does also happen sporadically, however: Dutch wenken 'wink', mengen 'mix' and merken 'notice' are weak, while Frisian winke, minge (Pattern G) and merke (Pattern K) are strong.

Some convergence of Frisian in the direction of Dutch has been described for the area of verbal inflection. In Interference Frisian, de Haan (1997: 70-72) writes, -je infinitives are replaced by $-e$ infinitives which are more similar to the Dutch forms. Additionally, many -je verbs 'become $e$-verbs via borrowing,' that is, they are replaced by non-cognate loans from Dutch with an -e infinitive. Both these developments cause a relative increase in the use of weak- 1 inflection at the expense of weak- 2 inflection, i.e., at the expense of the supposed default. There is also influence of Dutch on strong verbs in Interference Frisian (IF). Some verbs change their strong inflection to be more similar to Dutch: IF blike • bleek • bleken 'appear' (Fr. bliek • blykt; Du. blijken - bleek • gebleken), IF dûke • dook • doken 'dive' (Fr. dûkteldoek • dûkt, Du. duiken - dook - gedoken). Other verbs become weak (weak-1) when their cognate is weak in Dutch: dekke 'cover', strekke 'stretch', winke 'wink', krinke 'hurt', minge 'mix'. Given the pervasive influence of Dutch on all linguistic levels in (Interference) Frisian, a direct transfer of Dutch weak inflection is more likely here than a natural development towards weak inflection being speeded up by language contact. 


\section{Potential productivity of strong and weak inflection in Dutch}

In Knooihuizen and Strik (2014), we investigated the relative productivity potentials of verbal inflection patterns in Dutch. We performed three online experiments: (i) an elicitation task where participants were prompted to form past tense and perfect participle forms of nonce verbs, (ii) an acceptability judgment task on given weak and strong past tense and perfect participle forms of nonce verbs, and (iii) another elicitation task where participants were asked to provide strong past tense and perfect participle forms of existing weak verbs. Our results show a link between present-day native-speaker intuitions in production and perception, and historical tendencies in the development of Dutch.

First of all, there was a clear tendency for weak inflection over strong inflection, although at only two-thirds of forms, the preference was perhaps less clear than might have been expected on the basis of the overwhelming tendency of strong verbs to become weak. Within the group of strong verbs, secondly, they showed that in particular Classes I, II and III were particularly stable. These are-not coincidentally- the classes with the most members, and the classes from which relatively few verbs become weak. We also showed (Knooihuizen and Strik 2014: 194) that the oo and $o$ vowels (from Classes II and III) can be applied to form past tense and perfect participle verb forms regardless of stem vowel. The potential productivity of these $o$ forms, as we will refer to them here, is so strong that it even outperforms existing classes, such as Class VI; only verbs from Class I, a very large class that is phonologically clearly restricted to $i j$ stems, appear resistant. This finding is comparable to what Nowak $(2010,2015)$ has also found for German and Luxembourgish.

\section{Potential productivity of strong and weak inflection in Frisian}

We ran two experiments with speakers of Frisian to match the first two experiments from our study on potential productivity of inflection patterns in Dutch: an elicitation task and an acceptability judgment task, both with nonce words. Because the tasks for the Dutch and the Frisian speakers were identical, the results allow us to comment not only on the potential productivity of Frisian inflection patterns, but also on the influence of Dutch on the Frisian of our bilingual participants.

Compared to our Dutch results, we hypothesise, firstly, that our Frisian participants will produce fewer strong forms. Whereas Dutch strong verbs form a small number of large groups, Frisian strong verbs form considerably more and smaller groups, the lower type frequency meaning that the examples for analogous formation of strong forms are not as strong. Secondly, where we do find strong forms in the elicitation experiment, or positive evaluations in the acceptability experiment, we expect these forms to be parallel to the largest classes in Frisian, as was also found for Dutch; these patterns are blinke $\bullet$ blonk $\bullet$ blonken 'shine' (Pattern G), bite $\bullet$ biet $\bullet$ biten 'bite' (Pattern A), and bliuwe • bleau • bleaun 'stay' (Pattern B). Finally, we do not expect to find many $o$ forms in the Frisian elicitation data, as $o$ is not nearly as ubiquitous in the Frisian inflection system as it is in the Dutch one. Any $o$ forms that we do find, then, are probably due to Dutch influence. 


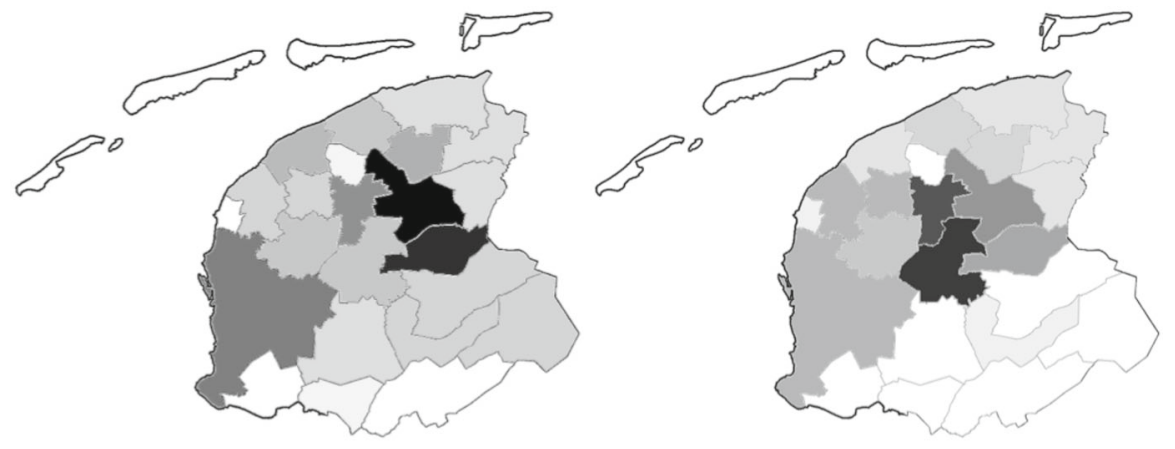

Fig. 1 Geographical origin of our respondents for the elicitation task (left) and acceptability judgment task (right), by municipality. Darker shading represents more informants from that municipality

\subsection{Elicitation task}

The first of our experiments was a written elicitation task, where we presented participants with an infinitive of thirty nonce verbs and asked them to provide the past tense and perfect participle. All infinitives presented had the $-e$ ending; we were therefore targeting forms according to a weak-1 or a strong pattern. The experiment was done through an online form in September 2013; instructions were given in written Frisian.

A total of 120 respondents completed the survey. The ages of the respondents ranged between 17 and 81 years, with particularly many respondents in the 1951-1960 and 1981-1990 cohorts. Our respondents were by definition bilingual in Dutch and Frisian, but two-thirds of our respondents claimed to use more Frisian than Dutch in daily life, with $43 \%$ using Frisian in more than $80 \%$ of their interactions. Only $8 \%$ of our respondents used more than $80 \%$ Dutch. Although the entire province of Fryslân was represented in our sample, the municipalities of Tytsjerksteradiel, Smallingerland and Súdwest-Fryslân were especially well-represented (Fig. 1). This seemingly unbalanced sample is mostly a function of population density. We do not expect it to be problematic, but it is worth being aware that results may be influenced by regional dialect patterns.

A summary of responses for this experiment is given in Tables 3 and 4 . The tables list the percentages of weak-1 and weak- 2 forms supplied for each verb, plus the most popular non-weak ('strong') form with the relevant percentage of responses. (Because we have chosen to focus on these three categories of responses, the totals per row do not add up to $100 \%$.) We also give the strong pattern we expected participants to follow based on analogy with existing strong verbs; an asterisk indicates analogy with nonprototypical members of the pattern in question. Frisian does not have a very strong standing as a written language, even among our intensive users of the language, and it is probably therefore that there was a great deal of variation in the responses; the data in these tables reflects our interpretation of these results, where we have lumped together what we think were spelling variants of the same response. ${ }^{4}$ This wide range

\footnotetext{
4 Although our informants are bilingual and may not be used to writing in Frisian, we are certain that the elicited verb forms are Frisian and not Dutch. Many responses are not in accordance with Dutch phonotactics,
} 
Table 3 Results of the elicitation experiment (past tenses)

\begin{tabular}{|c|c|c|c|c|}
\hline \multirow[t]{2}{*}{ Verb } & \multirow{2}{*}{$\begin{array}{l}\text { Expected } \\
\text { pattern }\end{array}$} & \multicolumn{3}{|l|}{ Past tense forms } \\
\hline & & Weak-1 (\%) & Weak-2 (\%) & Strong (\%) \\
\hline klite & A & klite (29\%) & $=$ & kliet $(29 \%)$ \\
\hline brite & A & brite $(21 \%)$ & $=$ & briet $(36 \%)$ \\
\hline miuwe & B & miuwde (83\%) & miuwe $(-)$ & теаи (13\%) \\
\hline briuwe & $\mathrm{B}$ & briuwde $(59 \%)$ & briuwe $(-)$ & breau $(40 \%)$ \\
\hline mieze & $\mathrm{C}$ & miesde $(80 \%)$ & mieze $(2 \%)$ & meas $(7 \%)$ \\
\hline giede & $\mathrm{C}$ & giede $(38 \%)$ & $=$ & gead $(13 \%)$ \\
\hline pjitte & $\mathrm{D}$ & pjitte (43\%) & $=$ & pjiet $(11 \%)$ \\
\hline klûpe & F & klûpte (81\%) & klûpe $(1 \%)$ & kloep (14\%) \\
\hline frûke & F & frûkte $(72 \%)$ & frûke (3\%) & froek $(12 \%)$ \\
\hline njinke & G & njinkte (54\%) & njinke $(2 \%)$ & njonk (34\%) \\
\hline strinke & G & strinkte $(38 \%)$ & strinke (3\%) & stronk $(54 \%)$ \\
\hline fjonke & G & fjonkte $(80 \%)$ & fjonke $(5 \%)$ & fjonk $(6 \%)$ \\
\hline skange & $\mathrm{G}^{*}$ & skangde (49\%) & skange (4\%) & skong $(37 \%)$ \\
\hline belke & $\mathrm{H}$ & belkte $(56 \%)$ & belke (4\%) & bolk (24\%) \\
\hline sjochte & $\mathrm{H}^{*}$ & sjochte $(50 \%)$ & $=$ & sjeach (18\%) \\
\hline frine & I & frynde $(61 \%)$ & frine $(2 \%)$ & frûn (18\%) \\
\hline smine & I & smynde $(83 \%)$ & smine $(-)$ & smûn $(10 \%)$ \\
\hline smerve & $\mathrm{K}$ & smerfde $(50 \%)$ & smerve $(5 \%)$ & $\operatorname{smurf}(18 \%)$ \\
\hline flerve & $\mathrm{K}$ & flerfde $(71 \%)$ & flerve (8\%) & flurf $(6 \%)$ \\
\hline tjerre & $\mathrm{L}$ & tjerde $(70 \%)$ & tjerre (3\%) & tjoar $(13 \%)$ \\
\hline skarre & $\mathrm{N}^{*}$ & skarde $(76 \%)$ & skarre $(7 \%)$ & skor $(6 \%)$ \\
\hline tjarre & $\mathrm{N}^{*}$ & tjarde $(82 \%)$ & tjarre $(3 \%)$ & tjor $(4 \%)$ \\
\hline bjekke & $\mathrm{O}$ & bjekte (83\%) & bjekke $(3 \%)$ & bjuts $(4 \%)$ \\
\hline frakke & $\mathrm{O}$ & frakte $(82 \%)$ & frakke $(4 \%)$ & friek $(8 \%)$ \\
\hline kêze & $\mathrm{P}$ & kêsde (40\%) & kêze (2\%) & kies $(26 \%)$ \\
\hline klette & $\mathrm{P}^{*}$ & klette $(42 \%)$ & $=$ & kliet $(17 \%)$ \\
\hline heppe & $\mathrm{P}^{*}$ & hepte $(90 \%)$ & heppe (一) & hiep (4\%) \\
\hline weie & none & weide (88\%) & weie $(-)$ & none given \\
\hline
\end{tabular}

of variation, much more than in our Dutch data, is the first finding we would like to point out.

A second finding which is immediately apparent from the data is the appearance of what looks like weak-2 forms, even though these are not expected according to normative grammar for the $-e$ infinitives presented. For some verbs, viz. those with a stem-final /d/ or /t/ (marked '=' in the tables), there is no difference between the weak-

Footnote 4 continued

and more importantly, the participles invariably lack the prefix $g e$ - which is obligatorily present in Dutch and obligatorily absent in Frisian. 
Table 4 Results of the elicitation experiment (participles)

\begin{tabular}{|c|c|c|c|c|}
\hline \multirow[t]{2}{*}{ Verb } & \multirow{2}{*}{$\begin{array}{l}\text { Expected } \\
\text { pattern }\end{array}$} & \multicolumn{3}{|l|}{ Participle forms } \\
\hline & & Weak-1 (\%) & Weak-2 (\%) & Strong $(\%)$ \\
\hline klite & A & klyt $(23 \%)$ & klite $(16 \%)$ & kliten (37\%) \\
\hline brite & A & bryt $(21 \%)$ & brite $(7 \%)$ & briten $(47 \%)$ \\
\hline miuwe & $\mathrm{B}$ & miuwd $(68 \%)$ & miuwe $(1 \%)$ & meaun $(28 \%)$ \\
\hline briuwe & B & briuwd $(35 \%)$ & briuwe (1\%) & breaun $(59 \%)$ \\
\hline mieze & $\mathrm{C}$ & miesd $(70 \%)$ & mieze $(9 \%)$ & miezen $(6 \%)$ \\
\hline giede & $\mathrm{C}$ & gied $(27 \%)$ & giede $(13 \%)$ & gieden $(16 \%)$ \\
\hline pjitte & $\mathrm{D}$ & pjit $(31 \%)$ & pjitte $(14 \%)$ & pjitten $(34 \%)$ \\
\hline klûpe & $\mathrm{F}$ & klûpt $(79 \%)$ & klûpe $(7 \%)$ & klûpen $(9 \%)$ \\
\hline frûke & $\mathrm{F}$ & frûkt $(77 \%)$ & frûke $(11 \%)$ & frutsen $(9 \%)$ \\
\hline njinke & G & njinkt $(50 \%)$ & njinke $(9 \%)$ & njonken (24\%) \\
\hline strinke & G & strinkt $(36 \%)$ & strinke $(5 \%)$ & stronken $(47 \%)$ \\
\hline fjonke & G & fjonkt $(62 \%)$ & fjonke $(14 \%)$ & fjonken (20\%) \\
\hline skange & $\mathrm{G}^{*}$ & skangd $(44 \%)$ & skange $(13 \%)$ & skongen (33\%) \\
\hline belke & $\mathrm{H}$ & belkt $(55 \%)$ & belke $(18 \%)$ & bolken $(10 \%)$ \\
\hline sjochte & $\mathrm{H}^{*}$ & sjocht $(46 \%)$ & sjochte $(15 \%)$ & sjochten $(23 \%)$ \\
\hline frine & I & frynd $(44 \%)$ & frine $(7 \%)$ & frûn $(36 \%)$ \\
\hline smine & I & smynd $(68 \%)$ & smine $(6 \%)$ & smûn $(9 \%)$ \\
\hline smerve & $\mathrm{K}$ & smerfd (39\%) & smerve $(16 \%)$ & smurven $(18 \%)$ \\
\hline flerve & $\mathrm{K}$ & flerfd $(49 \%)$ & flerve $(25 \%)$ & flurven $(11 \%)$ \\
\hline tjerre & $\mathrm{L}$ & tjerd $(61 \%)$ & tjerre $(17 \%)$ & tjoarn $(8 \%)$ \\
\hline skarre & $\mathrm{N}^{*}$ & skard $(75 \%)$ & skarre $(19 \%)$ & none given \\
\hline tjarre & $\mathrm{N}^{*}$ & tjard $(62 \%)$ & tjarre $(29 \%)$ & none given \\
\hline bjekke & $\mathrm{O}$ & bjekt $(72 \%)$ & bjekke $(12 \%)$ & bjutsen $(7 \%)$ \\
\hline frakke & $\mathrm{O}$ & frakt $(78 \%)$ & frakke $(11 \%)$ & frutsen $(4 \%)$ \\
\hline kêze & $\mathrm{P}$ & kêsd $(32 \%)$ & kêze (3\%) & kêzen $(41 \%)$ \\
\hline klette & $\mathrm{P}^{*}$ & klet $(32 \%)$ & klette $(22 \%)$ & kletten (28\%) \\
\hline heppe & $\mathrm{P}^{*}$ & hept $(86 \%)$ & heppe $(6 \%)$ & none given \\
\hline weie & none & weid $(86 \%)$ & weie $(2 \%)$ & none given \\
\hline
\end{tabular}

1 and weak-2 past tense forms, and we cannot tell which pattern our respondents followed. Where weak-2 forms can be distinguished, they were presented in some $3 \%$ of cases for past tenses but much more frequently (12\%) for participles. There are marked differences between verbs and verb groups.

Let us now move to the differences between verb groups. Given the multitude of patterns surveyed and the differences between the individual verbs within these small groups, it is more difficult to draw clear conclusions from the Frisian data than it is from Dutch data; the data are enough, however, to test our hypotheses and to comment on some other striking results. 
Our first hypothesis was that our Frisian data would show fewer strong forms than Dutch, because the wider variety of strong verbal inflection in Frisian would not provide the small set of clear example patterns that the conservative Dutch system does. The responses in the two languages are very comparable, however: $65 \%$ of the Frisian responses overall used the expected weak-1 inflection, and $68 \%$ of the Dutch responses did. As the sets of nonce test items are not entirely representative of the body of actual verbs in either language, and are biased towards forms that could result in strong inflection, and as the forms that differ from the canonical weak inflection are extremely varied, the actual potential productivity of strong inflection is probably quite a bit lower in both languages_-but still at comparable levels to each other.

The second hypothesis was that the more frequent patterns in Frisian would be more productive. This expectation was vindicated by the data, although there is a lot of variation between verbs within a pattern. Patterns G (blinke: njinke, strinke and fjonke), A (bite: klite, brite) and B (skriuwe: miuwe, briuwe) consistently score the highest percentages of strong responses. Note also the differences between past tense and past participle: in Patterns A and B the participle is 'stronger' than the past tense, but in Pattern G it is the other way round.

The final hypothesis concerned the use of $o$ as a strong past tense and past participle marker. The ubiquity of this vowel in strong nonce verb inflection in Dutch was one of the main findings from our Dutch study; we did not expect many $o$ forms in our Frisian data as the vowel occurs much less frequently in Frisian verbal inflection than in Dutch. And indeed, fewer than $4 \%$ of the elicited verb forms in Frisian contained a spelling likely to indicate $o$ forms, a much lower rate than in Dutch. ${ }^{5}$

The relative lack of $o$ responses is related to the fact that patterns of verbs (originally) belonging to the second strong class $(\mathrm{C}, \mathrm{D}, \mathrm{E}$, and F) were less productive in Frisian than in Dutch. In the latter language, these verbs are instrumental in providing analogues for the extension of /o/, but in Frisian, this is not the case. Furthermore, the second strong class is much less coherent in Modern Frisian than it was in Old and Early Modern Frisian (Strik 2015: 82-83), and than it is in Dutch.

\subsection{Acceptability judgment task}

Our second experiment mirrored that in Knooihuizen and Strik (2014): an acceptability judgment task with 50 nonce verbs. Participants were presented with a weak (weak-1) and a strong form of these verbs and were asked to indicate on a seven-point Likert scale which form they preferred. We designed two versions of the experiment: one group of participants judged the past tense form of one half of the set of verbs and the perfect participle form of the other, and vice versa.

The total number of participants for this experiment was 72 (28 and 44 in the two groups). Again the majority of respondents were frequent users of Frisian, with twothirds using more Frisian than Dutch. The participants in this experiment, however,

\footnotetext{
5 A notable exception is formed by the past tenses for the verbs skarre ( $6 \%$ skor, $6 \%$ skoar) and tjarre (4\% tjor), where the most frequent strong forms appear to be based on Patterns G, H, or L, despite a different stem vowel.
} 
were much younger on average than in the first experiment: although the age range was comparable, some $40 \%$ of respondents were under 30 years of age. The geographical distribution was also different, with Leeuwarden and Boarnsterhim providing most of the respondents, and no respondents from the southern and south-eastern municipalities of Fryslân (Fig. 1).

The mean scores for the individual verb forms in this experiment are given in Table 5. The polarity of the scores has been normalised so that scores closer to 1 indicate a preference for the weak form, and scores closer to 7 indicate a preference for the strong form. The overall mean score is 4.2, suggesting that respondents do not prefer weak over strong inflection or vice versa. The scores for inflection patterns and for individual forms within these patterns vary considerably, however, with the strong $i$ • $i e \cdot i$ pattern (Pattern A, mean score 5.5) being much preferred over weak inflections for the relevant verbs, while the $a \bullet o e \bullet a$ pattern (Pattern N, mean score 2.9) is much less popular and moreover shows more intra-group variation.

\subsection{Discussion}

We hypothesised that, given the much greater choice of strong inflection patterns in Frisian as compared to Dutch and therefore a much weaker pattern model, our Frisian respondents would show a greater preference for weak inflection than was found for Dutch. The overall rate of weak responses in the elicitation experiment, at $65 \%$, however, was comparable to the $68 \%$ found for Dutch (but cf. our comment in Sect. 2.2 above). Our hypothesis was also proven false by the results of the judgment task: with a score of 4.2 on a 7-point Likert scale, the Frisian respondents found strong forms much more acceptable than the Dutch respondents, who gave an average rating of 2.9 on the same scale.

We also suggested that the largest strong classes, i.e., those inflection patterns that had the highest type frequency, would show the fewest weak forms in the elicitation experiment. This was partly confirmed by the data: the two largest groups, of the njinke and klite types, had relatively fewer weak responses (50 and $27 \%$, respectively). The third-largest group, as in briuwe, however, yielded scores more or less on average with $60 \%$ weak responses. This is surprising as this pattern can be seen as iconically Frisian, and we would have expected these forms to yield scores well above average because of that salience.

Another remarkable result was the use of what are best described as weak- 2 forms (with an ending $-e$ ) in the preterite and past participle. While such forms are normally only used with infinitives ending in -je, speakers are apparently stimulated to use them even when the infinitive ends in - $e$, which we expected would only trigger weak-1 and strong inflections. ${ }^{6}$ This usage goes against the tendency in Interference Frisian of favouring weak-1 inflection over weak-2, since Dutch only has weak-1. This suggests that such interference was not a factor here.

The most plausible explanation for the use of these forms is that some participants, when they felt unable to come up with a good inflection for a particular verb, simply

\footnotetext{
${ }^{6}$ For this reason, the weak-2 forms were not tested in our acceptability task.
} 
Table 5 Results of the acceptability judgment experiment

\begin{tabular}{|c|c|c|c|c|c|c|c|}
\hline \multirow[t]{2}{*}{ Verb } & \multirow[t]{2}{*}{ Pattern } & \multicolumn{3}{|c|}{ Past tense pattern } & \multicolumn{3}{|c|}{ Participle pattern } \\
\hline & & Weak-1 & Strong & Score & Weak-1 & Strong & Score \\
\hline blite & A & blite & bliet & 5.98 & blyt & bliten & 5.39 \\
\hline fite & A & fite & fiet & 5.07 & $f y t$ & fiten & 5.32 \\
\hline gite & A & gite & giet & 5.64 & $g y t$ & giten & 5.68 \\
\hline grite & $\mathrm{A}$ & grite & griet & 5.68 & gryt & griten & 5.20 \\
\hline prite & $\mathrm{A}$ & prite & priet & 5.35 & pryt & priten & 5.71 \\
\hline feite & $\mathrm{A}^{*}$ & feite & fiet & 3.95 & feit & fiten & 4.26 \\
\hline sweike & $A^{*}$ & sweikte & swiek & 5.04 & sweikt & swiken & 3.09 \\
\hline briuwe & $\mathrm{B}$ & briuwde & breau & 5.43 & briuwd & breaun & 5.25 \\
\hline hiuwe & $\mathrm{B}$ & hiuwde & heau & 3.98 & hiuwd & heaun & 4.61 \\
\hline kiuwe & B & kiuwde & keau & 4.54 & kiuwd & keaun & 4.89 \\
\hline pliuwe & B & pliuwde & pleau & 4.30 & pliuwd & pleaun & 5.67 \\
\hline kiede & $\mathrm{C} / \mathrm{D}$ & kiede & kea & 4.33 & kied & kean & 3.61 \\
\hline rieze & $\mathrm{C} / \mathrm{D}$ & riesde & reas & 3.64 & riesd & reazen & 4.04 \\
\hline sieze & $\mathrm{C} / \mathrm{D}$ & siesde & seas & 4.43 & siesd & seazen & 4.02 \\
\hline swiede & $\mathrm{C} / \mathrm{D}$ & swiede & swea & 3.71 & swied & swean & 3.93 \\
\hline dreane & $\mathrm{C}^{*}$ & dreande & dreach & 2.54 & dreand & drein & 3.05 \\
\hline pleane & $\mathrm{C}^{*}$ & pleande & pleach & 3.30 & pleand & plein & 3.30 \\
\hline blûge & $\mathrm{F}$ & blûgde & bloech & 3.50 & blûgd & blûgen & 2.35 \\
\hline krûze & $\mathrm{F}$ & krûsde & kroes & 3.02 & krûsd & krûzen & 2.93 \\
\hline kûte & $\mathrm{F}$ & kûte & koet & 3.93 & $k \hat{u} t$ & kûten & 4.32 \\
\hline stûke & $\mathrm{F}$ & stûkte & stoek & 3.05 & $s t u ̂ k t$ & stûken & 3.14 \\
\hline binge & G & bingde & bong & 4.93 & bingd & bongen & 5.34 \\
\hline flinge & $\mathrm{G}$ & flingde & flong & 5.82 & flingd & flongen & 5.30 \\
\hline wrinke & $\mathrm{G}$ & wrinkte & wronk & 4.78 & wrinkt & wronken & 5.80 \\
\hline spinke & $\mathrm{G}$ & spinkte & sponk & 4.53 & spinkt & sponken & 4.82 \\
\hline tsjenke & $\mathrm{H}$ & tsjenkte & tsjonk & 5.05 & tsjenkt & tsjonken & 4.07 \\
\hline nenke & $\mathrm{H}$ & nenkte & nonk & 4.32 & nenkt & nonken & 4.75 \\
\hline ferljine & I & ferljynde & ferljûn & 3.75 & ferljynd & ferljûn & 4.89 \\
\hline fersnine & I & fersnynde & fersnûn & 4.14 & fersnynd & fersnûn & 3.57 \\
\hline gine & I & gynde & gûn & 3.89 & gynd & gûn & 4.35 \\
\hline mine & I & mynde & mûn & 3.26 & mynd & mûn & 3.44 \\
\hline strine & I & strynde & strûn & 3.64 & strynd & strûn & 4.48 \\
\hline ûntspine & I & ûntspynde & ûntspûn & 4.84 & ûntspynd & ûntspûn & 5.36 \\
\hline ûnttrine & I & ûnttrynde & ûnttrûn & 5.46 & ûnttrynd & ûnttrûn & 4.77 \\
\hline wrine & I & wrynde & wrûn & 3.88 & wrynd & wrûn & 4.64 \\
\hline dave & $\mathrm{N}$ & daafde & doef & 2.68 & daafd & daven & 2.07 \\
\hline kage & $\mathrm{N}$ & kaagde & koech & 3.57 & kaagd & kagen & 2.82 \\
\hline klave & $\mathrm{N}$ & klaafde & kloef & 2.91 & klaafd & klaven & 2.11 \\
\hline strage & $\mathrm{N}$ & straagde & stroech & 4.54 & straagd & stragen & 2.91 \\
\hline
\end{tabular}


Table 5 continued

\begin{tabular}{|c|c|c|c|c|c|c|c|}
\hline \multirow[t]{2}{*}{ Verb } & \multirow[t]{2}{*}{ Pattern } & \multicolumn{3}{|c|}{ Past tense pattern } & \multicolumn{3}{|c|}{ Participle pattern } \\
\hline & & Weak-1 & Strong & Score & Weak-1 & Strong & Score \\
\hline blekke & $\mathrm{O}$ & blekte & bluts & 4.61 & blekt & blutsen & 4.84 \\
\hline fjekke & $\mathrm{O}$ & fjekte & fjuts & 3.74 & fjekt & fjutsen & 4.43 \\
\hline swekke & $\mathrm{O}$ & swekte & swuts & 4.23 & swekt & swutsen & 4.50 \\
\hline fnekke & $\mathrm{O}$ & fnekte & fniek & 3.57 & fnekt & fnutsen & 3.64 \\
\hline klekke & $\mathrm{O}$ & klekte & kliek & 3.85 & klekt & klutsen & 4.09 \\
\hline plekke & $\mathrm{O}$ & plekte & pliek & 3.86 & plekt & plutsen & 4.36 \\
\hline kitte & $\mathrm{P}$ & kitte & kiet & 4.50 & kit & kitten & 4.50 \\
\hline knitte & $\mathrm{P}$ & knitte & kniet & 4.25 & knit & knitten & 4.80 \\
\hline njitte & $\mathrm{P}$ & njitte & njiet & 3.36 & njit & njitten & 5.11 \\
\hline kleone & none & kleonde & kloan & 2.41 & kleond & kloan & 3.32 \\
\hline speoke & none & speokte & spoak & 4.00 & speokt & spoaken & 3.34 \\
\hline
\end{tabular}

used the Frisian 'default' weak-2 form despite an incompatible - $e$ infinitive; the characterisation of weak-2 as 'default' is strengthened here as there appear to be fewer morphological constraints on its application than reference grammars suggest. We also note that, contrary to the generalisation from Haverkamp et al. (submitted), the verbs with relatively many weak-2 responses ( $>10 \%$ in Tables 3,4$)$ have simple codas as often as they have complex codas. It is possible that this is an overgeneralisation of an unmarked (default) or marked (Frisian, non-Dutch) feature (Campbell and Muntzel 1989: 187-189), although they describe this in the context of language death and our participants are fully fluent speakers of the language.

It should also be noted that these unexpected weak- 2 forms were much more frequent in the past participle than in the past tense. Again, it is not obvious why this would be the case, since the weak- 2 forms for both tenses are identical, and therefore equally (non)distinct from the infinitive. One possible explanation is that in the participle, the weak-2 form is phonologically highly similar to a strong participle where the vowel is identical to the stem vowel (an ABA pattern). This goes especially for Standard Dutch pronunciation, which omits the final $-n$ in the participle. ${ }^{7}$ Such ABA participles could at least have reinforced the idea that weak- 2 forms are a viable option.

Just as there was a difference in frequency between the application of weak- 2 inflection in the past tense and the past participle, we find frequency differences between the forms for strong inflection as well. In many cases, strong responses were supplied more often for the past participle, but this is far from always the case, and which of the two forms has the highest frequency of strong responses is not transparently constrained by inflection pattern. This finding is potentially interesting because data were elicited as a paradigm - in itself a familiar task for our participants from foreign language learning in secondary school-but the differences between the past tense and past participle forms suggest that participants must have generated their responses separately

\footnotetext{
7 In Frisian and much Frisian-accented Dutch, the final /n/ would be pronounced, however.
} 
as forms rather than together as a paradigm, and as such questions the integrity of the paradigm (cf. Stump 2015: 16-30). A follow-up experiment comparing forms elicited separately to forms elicited paradigmatically may shed further light on this issue.

As a side note, we would like to mention an interesting result from our acceptability judgment task regarding the past tense of 'assibilation verbs' in -ekke. Frisian dialects vary in their use of -iek (regular phonological development) or -uts (formed analogically from the participle in -utsen). The -uts forms appear to have spread from the Southwest, say Loopstra (1937) (also for -its) and Dyk (2015); van der Veen (2001: 110) has -uts forms for the three major dialect groups. Our experiments with young participants from mostly northern dialects show that the -uts forms are more acceptable, suggesting that this change is running to completion.

\section{Discussion and conclusion}

In both the synchronic usage of Frisian and the experimental results presented here, we see that Frisian has a greater number of different inflection patterns and more variation than Dutch. Whereas in Dutch potential productivity is mostly limited to three inflectional strategies - weak, a few highly frequent canonical strong patterns, and $o$ Frisian speakers show a more diffuse pattern of usage, where the expected weak-1 and canonical strong patterns cede some space to unprompted weak-2 inflectional forms and many miscellaneous inflections. This makes the picture of potential productivity for Frisian verbal inflection less clear than it is for Dutch. As in Dutch, however, a higher type frequency of strong inflection patterns generally means a higher potential productivity of the pattern.

This is in line with the diachronic relation between frequency and class shift observed between Early Modern and Modern Frisian by Versloot and Strik (published in Strik 2015: 165-177). Here it is shown that analogical similarity and the class size of the target inflection class determine the direction of change for a verb's class shift, while the token frequency of the verb in question can act as either a stabilising or destabilising influence, making class shift more or less likely. Since the nonce verbs used in our experiments have no practical token frequency, it is solely analogical similarity and target class size that determine the preferred inflection of the verb.

Our results reveal that there is no pronounced influence of Dutch strong inflection forms on those of our Frisian speakers, despite the fact that all of them are bilingual. While studies of Interference Frisian (de Haan 1997) reveal that such influences may occasionally be found, our data suggest that they are rare, particularly in writing when speakers are given time to consider what the most suitable inflection for a given verb would be. (It is possible that a spoken task would produce different results.) Instead of Dutch influence, the forms provided by our participants show quite a few prototypically Frisian forms, such as the unexpected use of weak-2 participles for many verbs and strong forms like -uts(en) and -eau(n), while showing almost no sign of typically Dutch phenomena (spread of $o$, and past tense $i e$ before $r \mathrm{C}$ in Class III).

These results may have been influenced by the composition of our participant group. Around two thirds of them are Frisian-dominant speakers, which may mean that they are less influenced by Dutch since (i) they use it less than they use Frisian, and (ii) they 
use it less than other Frisian speakers who use Dutch more often in their daily lives. In addition, the task may have prompted hyper-Frisian results, since it was explicitly about Frisian and presented in Frisian, and since writing in Frisian is an unusual task for many Frisian speakers. All of these factors may have led to a heightened awareness of which forms were the 'best' Frisian (geef Frysk) forms.

Based on data from the history of German, Carroll et al. (2012) argue that periods of increased language and dialect contact lead to a higher degree of regularisation in Germanic verb systems. This is not directly borne out by our results: while speakers of Frisian experience both Frisian dialect contact and language contact with Dutch, they do not produce more weak or 'regular' inflections, nor do they rate such forms more acceptable than strong forms. Rather, comparing our results to similar studies on other languages leads us to conclude that first and foremost, language contact leads to instability in grammar. Whether this instability then results in regularisation, increased variation, convergence to a contact language, or a combination of these, depends on the situation in question. More empirical research is needed to discover which factors favour which outcome of language contact.

Acknowledgements It takes a village to raise a child. Likewise, it takes a scholarly community to produce a journal article. Thanks are due to conference audiences in Groningen, Leeuwarden and Berlin for their insightful questions and discussion, and to JCGL editor Jim Wood and three anonymous reviewers for detailed and often harsh-but-fair comments on the first submission. Tige tank, also, to our 192 Frisian participants without whom this study would not exist. We have tried our best to explain the experimental results; any shortcomings remain, as always, ours.

Open Access This article is distributed under the terms of the Creative Commons Attribution 4.0 International License (http://creativecommons.org/licenses/by/4.0/), which permits unrestricted use, distribution, and reproduction in any medium, provided you give appropriate credit to the original author(s) and the source, provide a link to the Creative Commons license, and indicate if changes were made.

\section{References}

Bowern, Claire. 2013. Relatedness as a factor in language contact. Journal of Language Contact 6 (2): 411-432.

Breuker, Pieter. 2001. West Frisian in language contact. In Handbuch des Friesischen, ed. Horst Haider Munske, 121-129. Tübingen: Niemeyer.

Campbell, Lyle, and Martha C. Muntzel. 1989. The structural consequences of language death. In Investigating obsolescence: Studies in language contraction and death, ed. Nancy C. Dorian, 181-196. Cambridge: Cambridge University Press.

Carroll, Ryan, Ragnar Svare, and Joseph Salmons. 2012. Quantifying the evolutionary dynamics of German verbs. Journal of Historical Linguistics 2 (2): 153-172.

Clahsen, Harald. 1997. The representation of participles in the German mental lexicon: Evidence for the dual-mechanism model. In Yearbook of Morphology 1996, ed. Geert Booij, and Jaap van Marle, 73-95. Dordrecht: Kluwer.

Cuskley, Christine F., Francesca Colaiori, Claudio Castellano, Vittorio Loreto, Martina Pugliese, and Francesca Tria. 2015. The adoption of linguistic rules in native and non-native speakers: Evidence from a Wug task. Journal of Memory and Language 84: 205-223.

Dammel, Antje. 2011. Konjugationsklassenwandel. Prinzipien des Ab-, Um-, und Ausbaus verbalflexivischer Allomorphie in germanischen Sprachen (Studia Linguistica Germanica 103). Berlin: De Gruyter.

de Haan, Germen J. 1997. Contact-induced changes in modern West Frisian. Us Wurk 46: 61-89.

De Backer, Lennert. 2013. Die Entwicklung der starken Verben in den nordgermanischen Sprachen: zugleich im Hinblick auf andere germanische Sprachen. Universiteit Gent MA thesis. 
Dyk, Siebren. 2015. Strong and other irregular verbs. Taalportaal. http://taalportaal.org/taalportaal/topic/ pid/topic-13998813312203318. Accessed 18 January 2016.

Dyk, Siebren. 2007. Jorwert breaking: A late Old West Frisian sound change. In Advances in Old Frisian philology, ed. Rolf H Bremmer Jr., Stephen Laker, and Oebele Vries, 91-128. Amsterdam: Rodopi.

Eisma, Dick, and Jan Popkema. 2004. Tiidwurden. Ljouwert (Leeuwarden): Afûk.

Geerts, G., W. Haseryn, J. de Rooij, and M.C. van den Toorn. 1984. Algemene Nederlandse Spraakkunst. Groningen: Wolters-Noordhoff.

Gorter, Durk. 2001. Extent and position of West Frisian. In Handbuch des Friesischen, ed. Horst Haider Munske, 73-83. Tübingen: Niemeyer.

Haverkamp, A.R., Arjen P. Versloot, and Hedde Zeijlstra. submitted. All you need is rules: A study on the relationship of markedness between two classes of Frisian regular verbs.

Heinsius, J. 1897. Klank- en buigingsleer van de taal des Statenbijbels. Groningen: Noordhoff.

Hilton, Nanna Haug, and Charlotte Gooskens. 2013. Language policies and attitudes towards Frisian in the Netherlands. In Phonetics in Europe: Perception and production, ed. Charlotte Gooskens, 139-157. Frankfurt am Main: Lang.

Hoekstra, Jarich F. 1998. Fryske wurdfoarming. Ljouwert (Leeuwarden): Fryske Akademy.

Jacobs, Neil G. 2005. Yiddish: A linguistic introduction. Cambridge: Cambridge University Press.

Knooihuizen, Remco, and Oscar Strik. 2014. Relative productivity potentials of Dutch verbal inflection patterns. Folia Linguistica Historica 35: 173-200.

Loopstra, J.J. 1937. It forkringen fen it imperf. briek ensf. troch de analogy-foarm brits ensf. yn it moderne Frysk. In Frysk Jierboek 1937, ed. P. Sipma, and J.H. Brouwer, 99-101. Assen: Van Gorcum.

Matras, Yaron. 2009. Language contact. Cambridge: Cambridge University Press.

Moder, Carol Lynn. 1992. Rules and analogy. In Explanation in historical linguistics, ed. Garry W. Davis, and Gregory K. Iverson, 179-191. Amsterdam: Benjamins.

Nowak, Jessica. 2010. Im Spannungsfeld starker und schwacher Verben: zur Entstehung einer "8. Ablautreihe" im Deutschen, Niederländischen und Luxemburgischen. In Kontrastive Germanische Linguistik, vol. 2, ed. Antje Dammel, Sebastian Kürschner, and Damaris Nübling, 429-472. Hildesheim: Olms.

Nowak, Jessica. 2015. Zur Legitimation einer 8. Ablautreihe: Eine kontrastive Analyse zu ihrer Entstehung im Deutschen, Niederländischen und Luxemburgischen. Hildesheim: Georg Olms.

Pijpops, Dirk, Katrien Beuls, and Freek Van de Velde. 2015. The rise of the verbal weak inflection in Germanic: An agent-based model. Computational Linguistics in the Netherlands Journal 5: 81-102.

Ragnarsdóttir, Hrafnhildur, Hanne Gram Simonsen, and Kim Plunkett. 1999. The acquisition of past tense morphology in Icelandic and Norwegian children: An experimental study. Journal of Child Language 26 (3): 577-618.

Seebold, Elmar. 1970. Vergleichendes und etymologisches Wörterbuch der germanischen starken Verben. Den Haag: Mouton.

Siegel, Jeff. 2001. Koine formation and creole genesis. In Creolization and contact, ed. Norval Smith, and Tonjes Veenstra, 175-197. Amsterdam: Benjamins.

Strik, Oscar. 2014. Stability and change in strong verb inflection between Old and Early Modern Frisian. Amsterdamer Beiträge zur älteren Germanistik 73: 449-496.

Strik, Oscar. 2015. Modelling analogical change: A history of Swedish and Frisian verb inflection. Groningen: Rijksuniversiteit Groningen dissertation.

Stump, Gregory. 2015. Inflectional paradigms: Content and form at the syntax-morphology interface. Cambridge: Cambridge University Press.

Swarte, Femke, and Nanna Haug Hilton. 2013. Mutual intelligibility between speakers of North and West Frisian. In Phonetics in Europe: Perception and production, ed. Charlotte Gooskens, 281-302. Frankfurt am Main: Lang.

Thomason, Sarah Grey. 2010. Contact explanations in linguistics. In The handbook of language contact, ed. Raymond Hickey, 31-47. Oxford: Wiley-Blackwell.

van den Berg, B. 1957. De ie van bedierf, stierf, wierf, wierp en zwierf. Taal \& Tongval 9: 75-84.

van der Veen, Klaas F. 2001. West Frisian dialectology and dialects. In Handbuch des Friesischen, ed. Horst Haider Munske, 98-116. Tübingen: Niemeyer. 